\title{
SS-059 児童虐待に立ち向かうために
}

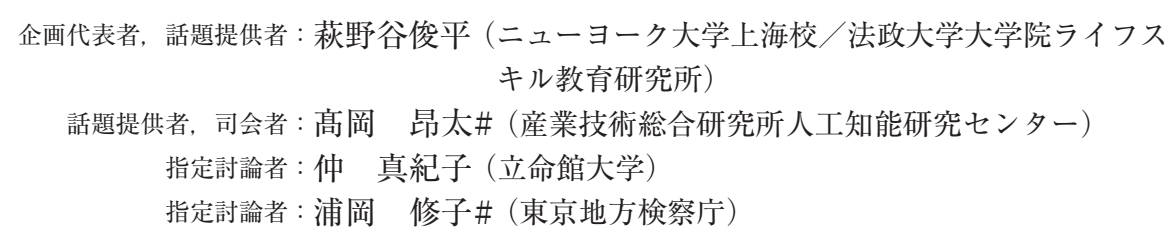

児童虐待防止については, 近年, これまで以上に大きな社会的関心を集めている。児童虐待対策を進 めるべく, 2019年 3 月19日に, 政府は児童虐待防止法などの改正案を閣議決定した。また, 虐待の被害 児童などへの面接については, 厚生労働省, 最高検察庁, 警察庁の各機関は, 2015年10月28日付および 2018年 7 月24日付で, 被害児童の負担軽減および供述の信用性確保の観点から, 三機関協同で方針を検 討したうえで代表者が面接を実施し，さらにはその後の情報共有を推進するための通知を発出している。

こうした背景を踏まえ, 本シンポジウムでは, 児童虐待に立ち向かうために, 心理学だけでなく, 情 報工学などの多領域の知見も融合して進められている最新研究の成果について, 各話題提供者から報告 いただく。その後, これまでに児童虐待に携わってきた心理学者と法曹, それぞれの指定討論者の視座 からの討論を踏まえたうえで, 今後の展望も含めて議論したい。

\section{第2 日 9 月12日(木) $13: 20 \sim 15: 20$}

\section{SS-060「変化する知覚」の諸相一視知覚・嗅知覚の時間変動に関する知 見から一}

\author{
企画代表者, 司会者：境敦史 (明星大学) \\ 企画者, 指定討論者: 小松 英海 (慶應義塾大学) \\ 企画者: 増田 知尋 (文教大学) \\ 話題提供者 : 新井 哲也 (神奈川大学) \\ 話题提供者: 小川緑 (筑波大学)
}

知覚を「物理的刺激によって引き起こされる生理学的過程の結果」と見なすと, 知覚は個体に封入さ れた主観像と捉えられ, 知覚研究の関心は物理的刺激と主観との咀龉や両者の関数的関係にのみ集中し てしまう。

これに対して, アリストテレス, ブレンターノ, ギブソンのように, 生きて環境に働きかける可能性 を備えた身体 (生活体) と環境との関わりを知覚と捉えることで，（1）環境は他者と共有されているの で，知覚を主観像と見なしたり，知覚を客観的世界の中で生じる主観と見なす考えを克服できる。さら に, (2) 知覚が「環境との, 刻々と変化する関わり」である限りにおいて, 変化を知覚の本質と見なす 視点 (過程存在論) が必然的に招来される。本シンポジウムでは, 知覚の時間的な変化に関する視知覚 と嗅知覚の領域における知見の紹介を承け, 知覚を「共有される環境における行為・過程・関係」と見 なす視点から，知覚研究の新たな展開を探りたい。 